\title{
Impediments to Capital Market Financing of Small and Medium Enterprises in Nigeria
}

\author{
Nwakoby Clement ${ }^{1}$ and Okoye Lawrence Uchenna ${ }^{2 *}$ \\ ${ }^{1}$ Department of Banking \& Finance, Nnamdi Azikiwe University, Nigeria \\ ${ }^{2}$ Department of Banking \& Finance, Covenant University, Nigeria \\ *Corresponding author: Okoye Lawrence Uchenna, Department of Banking \& Finance, Covenant University, Ota, Nigeria
}

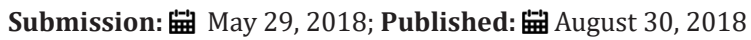

\begin{abstract}
This paper examined why Small and Medium Enterprises (SMEs) do not procure long term funds from the capital market as well as ascertain the conditions under which small and medium enterprises will be enabled to source funds from the capital market. It gives an insight that may help owners of SMEs in Nigeria to know other options of accessing long term funds from the capital market; the unending benefits associated with listing on the capital market as well as the terms and conditions for enlisting on the exchange. The study adopted a descriptive survey. 80 small and medium enterprises in Anambra state were sampled, 40 each from Onitsha and Nnewi. The choice of the two areas was guided by the fact that they have large clusters of small and medium enterprises in the state. Questionnaires were administered on the owners of these SMEs and/or representatives (in cases where the owner was not available at the time of administering the questionnaire). The data generated from the survey were tested using the ChiSquare (X2). Simple tabulation was used to present the survey findings, percentage distribution of the respondents was equally presented. The study reveals that information about the activities of the capital market among SMEs specifically, in respect of its relevance to access long term finance is still very low. The few SMEs that are aware fear losing control of their companies to wealthy shareholders. The study also finds that the listing requirements constitute major constraints to procuring long term finance by SMEs. In the light of this, the Nigerian Stock Exchange should carefully consider the constraints highlighted by the respondents with a view to reviewing them for the benefit of SMEs in line with global best practices. The regulatory authorities should formulate policies that would engender a more investment friendly climate particularly in the areas of infrastructure, interest rate, inflation, etc. to make procurement of long term finance more attractive to investors..
\end{abstract}

Keywords: Industrialization; Catalyzing development; Employment; Urban and rural; Small and Medium sized enterprises

Abbreviations: SMEs: Small and Medium Sized Enterprises; CBN: Central Bank of Nigeria; ASeM: Alternative Securities Market; NCI: National Council on Industry; NSE: Nigerian Stock Exchange; CAC: Corporate Affairs Commission; SEC: Securities and Exchange Commission; ICT: Information and Communication Technology; NIDB: Nigeria Industrial Development; PBN: Peoples Bank of Nigeria; NERFUND: National Economic Reconstruction Fund; BOI: Bank of Industry; ADB: Africa Development Bank; IFC: International Finance Corporation; GDP: Gross Domestic Product

\section{Introduction}

Small and Medium sized Enterprises (SMEs) are the backbone of all economies and a key source of economic growth, job creation and innovation in both developed and emerging market economies. Hallberg [1], Olutunla [2] and Williams [3] noted that both in developing and developed countries, small and medium scale enterprises play critical role in the process of industrialization and economic growth by importantly contributing to employment, income generation and catalyzing development in urban and rural areas. In the light of this, different governments in the world offer different types of loans, guarantees and other supporting measures to facilitate these SMEs access to capital.

Evidence from previous studies shows that SMEs financing primarily depend on bank loans. The majority of commercial bank loans offered to SMEs are often limited to periods far too short to pay off any fairly large investment Fayomi et al. [4]. Furthermore, banks in many developing countries prefer to lend to government rather than private sector borrowers because the risk is lesser and higher returns are expected [5]. This is why the Governor of Central Bank of Nigeria (CBN), Emefiele in his first press briefing on June $5^{\text {th }} 2014$ stated that he will reduce Nigeria Treasury bill rate to discourage banks from investing much in government securities. However, the banking crisis in Nigeria revealed that bank financing is not a reliable source of financing, especially during periods of systemic stress. Moreover, the regulatory measures taken after the crisis, such as strengthened rules on capital requirements, create additional challenges on the financing of SMEs through bank loans. Consequently, the need for diversified funding sources for SMEs is more urgent now than ever.

Though a suitable source of long-term finance needed for venture purposes, the contribution of the capital markets to SMEs 
funding is rather quite negligible in spite of the efforts of the government and regulators to promote SMEs financing through the capital market. Such efforts include the establishment of the firsttier market and the second-tier market or the Alternative Securities Market (ASeM) where the listing and disclosure requirements are relaxed to accommodate business units like the SMEs. A lot of issues have been raised as reasons for the lack-lustre performance of the capital market with regard to SMEs financing. They include, cumbersome listing requirements; reluctance on the part of the business owners to embrace transparency in reporting and disclosure standards; unwillingness to cede a part of the business to outsiders for fear of losing control; weak capital structure; low managerial skills and lack of access to modern technology FSS 2020 SMEs Sector Report, 2007.

The fragile business economic environment and the absence of the requisite infrastructure have rendered SMEs practice costly and ineffective, thereby worsening their credit competitiveness. There are limited documented financials on their activities as well as authentic data on them.

Given the crucial role of SMEs to the Nigerian economy, since independence in the 1960s, different regimes of governments have targeted various programmes and spent huge amount of money with the sole aim of developing this sector (SMEs), however, these have not yielded any significant results Mambula, 1997 as witnessed in the current condition of SMEs in the country. Oboh 2002; Okpara 2000 and Wale-Awe 2000 note that SMEs are generally subjected to influence and only a certain number of them manage to survive due to several factors such as difficulty in accessing credits from banks and other financial institutions; harsh economic conditions which results from unstable government policies; gross undercapitalization; inadequacies resulting from the highly decayed state of infrastructural amenities, astronomically high operating cost; lack of transparency and high rate of corruption; and lack of interest and lasting support for the SMEs sub-sector by the government authorities.

The financial system in every economy plays a key role in the development and growth of the economy, although the ability to play this role effectively and efficiently depends largely on the state of development of the financial system. The traditional commercial banks are the key players in the financial system of almost every economy, have the capability of pulling financial resources together to meet the credit needs of SMEs. Nevertheless, there is still a huge gap between supply capabilities and the financing needs of the SMEs. In Nigeria, the situation is even more widespread as noted by Olutunla et al. [2].

Against this background, this paper aimed at identifying and critically examining the major obstacles to financing Small and Medium Enterprises (SMEs) from the Nigerian capital market. In the course of the study an in-depth analysis will be made and possible methods suggested by which SMEs can access long term funds from the capital market.

\section{Conceptual framework}

The capital market is a financial market segment established for the mobilization and utilization of long-term funds for social, economic and industrial development Modinat et al. [6]. The instruments traded in the capital market include company shares (equities), government bonds, and mortgage loans. Investopedia defined the capital market as a market for buying and selling of equity and debt instruments. Capital market channels savings and investment between suppliers of capital such as retail investors and institutional investors, and the users of capital like businesses, government and individuals. Capital markets are vital to the functioning of an economy, since capital is a critical component of generating economic output. According to Oteh 2010 capital markets are a viable way of increasing financing options to SMEs and would ultimately serve to develop the SMEs. The ability of companies in the early stages of development to raise fund in the capital markets is beneficial because it allows these companies to grow very quickly. The growth in turn speeds up the dissemination of new technologies throughout the economy. However, she posits that most African capital markets currently do not have the depth and liquidity to support the financing of SMEs. Capital markets are important source of long term finance, especially since SMEs have been primarily dependent on banks financing. Indeed a financial system that is built on the two pillars of banking and securities markets is stronger than a system that is built solely on banking credit since a well-functioning system would be comprised of various sources of finance. Oteh et al. 2010 stated that the choice of banks or the market would depend on the needs of the SMEs. The capital market can and should compete head on with banks in the supply of debt finance to businesses including those to SMEs.

Components of the capital market include primary markets, where new stocks and bonds are issued and sold to investors, and the secondary markets, which trade existing securities. Capital markets are distinct from the money markets, which refers to markets for financial instruments with maturities not exceeding one year. The size of a nation's capital market is directly proportional to the size of its economy. The United States, the world largest economy, has the largest and deepest capital market. In Nigeria, participants in the market include the Nigerian Stock Exchange, Discount Houses, Development Banks, Investment Banks, Building Societies, Stockbroking Firms, Insurance and Pension Organizations, Quoted Companies, the Government, Individuals, and the Nigerian Securities and Exchange Commission Anyanwu et al. [7]

\section{Definition of Small and Medium Enterprises (SMEs)}

At present, there is no generally accepted or universal definition of SME as its definition varies from country to country. Various government ministries, research institutes, agencies, private sector institutions, etc. use different definitions. However, among the various definitions, there is a convergence of opinion which comes to define SMEs in terms of asset values and the number of people employed. The following are some of the definitions of SMEs as documented in literature: 
a. In the United States, small businesses that are defined by the number of employees, refer to those with fewer than 100 employees, while medium-sized business often refers to those with fewer than 500 employees Oteh 2010.

b. In the European Union (EU), companies with fewer than 10 employees are defined as "micro", those with fewer than 50 employees as "small", and those with fewer than 250 as "medium".

c. The Organization for Economic Co-operation and Development OECD, 2000 views SMEs as firms with fewer than 500 employees.

d. For developing countries, small-scale enterprises would generally mean enterprises with less than 50 workers and medium-size enterprises would usually mean those that have 50-99 workers.

e. Also the National Economic Reconstruction Fund (NERFUND) defines SMEs as those in which fixed assets and new investment do not exceed N10million [8].

f. For the Central Bank of Nigeria, SMEs (for commercial bank lending) are in the industrial sector, which excludes general commerce, whose total investment does not exceed N2.5million (excluding land and working capital) or whose maximum turnover is N2.5million annually and N5million investment and N25million turnover respectively for merchant banks.

g. National Council on Industry (NCI) defines SMEs in terms of employment i.e. as one with between 10 and 300 employees [9].

h. Finally, the Enterprises Promotion Decree of 1989 as amended in 1994 defines small-scale business as any enterprise set up to make the owner self-employed and self-reliant. Such businesses include business centres, organised mechanics and allied artisans such as electricians, panel-beaters, super markets, gift shops and so on. Emphasis is not laid on the amount of capital or on the number of employees engaged by the business but on creating employment for owners.

\section{The Alternative Securities Market (ASeM) of the Nigerian Stock Exchange (NSE)}

The Alternative Securities Market (ASeM) is a specialized arm of the Nigerian Stock Exchange (NSE) for small and medium scale enterprises with potentials for growth. ASeM provides the opportunity for these enterprises to raise long term capital at relatively low cost from the capital market, while creating opportunities for growth and institutionalization of enterprises listed on the exchange. On the ASeM, there is no limit to the amount of capital an enterprise can raise. The company must comply with relevant requirements of the Corporate Affairs Commission (CAC) and the Securities and Exchange Commission (SEC). The companies operating in these sectors - Agriculture, Construction/ Real Estate, Consumer Goods, Financial Services, Healthcare,
Industrial Goods, Information and Communication Technology (ICT), Natural Resources, Oil and Gas Services are listed on the ASeM. The simplified listing requirements, which constitute the basic distinguishing features of the ASeM are that prospective companies must:

a. Be duly registered as a Public Liability Company under the Companies and Allied Matters Act;

b. Have been fully operational for not less than two years;

c. Have a comprehensive business plan and audited financial statement of accounts;

d. Invite public investors are to hold not less than 15\% of total share of the company, while pre-listing investors hold a maximum of $85 \%$ stake;

e. Ensure that post IPO promoters are required to retain a period of 12 months, at least $50 \%$ of shares held prior to the IPO;

f. Have shareholders of not less than 51 in compliance with the International Financial Reporting Standard (IFRS);

g. Employ ASeM appointed designated adviser;

h. Pay annual listing fees of N200,000.

Given the above conceptual clarifications on capital market, Alternative Securities Market and the definition of SMEs, it is evident that the SMEs fall under the Alternative securities market (ASeM), but investors usually see the ASeM stock as inferior to the NSE stock. Hence, trading in ASeM stocks tends to be sparse. This adversely affects both stock prices and liquidity. The potential of an ASeM listing is thus a meagre inducement for SMEs and potential investors. It therefore follows that the Nigerian Capital Market can develop the SMEs, through a more appropriate policy framework in order to assist in the overall development of the Nigerian economy.

\section{Relationship between the financial system and the Small and Medium Enterprises (SMEs)}

A critical examination of the relationship that exists between the SMEs and Nigerian financial system reveals clearly an apathy that is directed towards small businesses by financial system and resentment on the part of the SMEs towards the financial market. This is despite the numerous government established developmental programs and policies to bridge the lacuna between the financial system and SMEs sub-sector. [10] chronicles these efforts to include:

a. Provision of direct financial assistance through government owned financial institutions which includes the Nigeria Agricultural Bank (NAB), Urban Development Bank (UDB), Federal Mortgage Bank of Nigeria (FMBN), etc.

b. Provision of packages of subsidized or discounted loan portfolio through special schemes arrangement between government and commercial banks. For instance, in 2001 the Medium Industries Scheme was established. This requires banks to 
set aside $10 \%$ of their gross profit before tax for equity investment in SMEs.

c. Provision of capital to SMEs through soft loans advanced by government owned financial institutions such as the Nigeria Industrial Development (NIDB), the Peoples Bank of Nigeria (PBN) the National Economic Reconstruction Fund (NERFUND), now known as the Bank of Industry (BOI)

d. Funding of SMEs in liaison with multilateral financial institutions such as the World Bank, the Africa Development Bank (ADB), and the International Finance Corporation (IFC) etc. For instance, in 1989, the World Bank gave Nigeria a facility of 270 million US dollars out of which a total of 267.7 million US dollars was set aside for lending to SMEs through eligible participating banks.

e. Issuance of directive on mandatory credits to SMEs through the Central Bank of Nigeria (CBN) guidelines to commercial banks. In 1992, the Federal Government through the CBN directed commercial banks to mandatorily allocate $20 \%$ of their credits to SMEs.
Osa Afiana [11] observed that this scheme was only partially successful mainly due to reluctance of banks to advanceloans to SMEs without collateral security and the appropriate credit guarantee scheme. Some banks did not comply and were more interested and comfortable paying the penalty attached to default. This directive was eventually abolished in 1996. From the records of CBN, it is observed that though traditional commercial banks have been experiencing aggregate credit growth to the domestic economy, the ratio of loans of small-scale enterprises to commercial banks total credit to the economy has continued to decrease over the years and it takes only a mandatory enforcement by the government to get the commercial banks lend to SMEs. Table 1 shows that in 1992 when the directive to allocate at least $20 \%$ of total credit to SMEs ratio of aggregate bank loans to the sub-sector stood at 48.8\%. Apparently, for reasons advanced by Osa Afiana [11], this ratio declined to $25.0 \%$ in 1996 when the directive was lifted. From 1997 to 2012, the ratio of bank lending to SMEs declined from $17.0 \%$ (1997) to $0.13 \%$ (2012); a clear evidence that banks naturally shy away from lending to the SMEs sub-sector unless compelled to do so (Table 1).

Table 1: Ratio of loans to SMEs by commercial banks.

\begin{tabular}{|c|c|c|c|}
\hline Year & $\begin{array}{l}\text { Commercial Banks Loans to } \\
\text { SMEs (N'Million) }\end{array}$ & $\begin{array}{l}\text { Commercial Banks total credits } \\
\text { (N'Million) }\end{array}$ & $\begin{array}{l}\text { Commercial Banks Loans to SMEs as a Per- } \\
\text { centage of Total Credit }(\%)\end{array}$ \\
\hline 1992 & $20,400.00$ & $41,810.00$ & 48.8 \\
\hline 1993 & $15,462.90$ & $48,056.00$ & 32.2 \\
\hline 1994 & $20,552.50$ & 92.624 .0 & 22.2 \\
\hline 1995 & $32,374.50$ & $1,41,146.00$ & 22.9 \\
\hline 1996 & $42,302.10$ & $1,69,242.00$ & 25 \\
\hline 1997 & $40,844.30$ & $2,40,782.00$ & 17 \\
\hline 1998 & $42,260.70$ & $2,72,895.50$ & 15.5 \\
\hline 1999 & $46,824.00$ & $3,53,081.10$ & 13.3 \\
\hline 2000 & $44,542.30$ & $5,08,302.20$ & 8.7 \\
\hline 2001 & $52,428.40$ & $7,96,164.80$ & 6.6 \\
\hline 2002 & $82,368.40$ & $9,54,628.80$ & 8.6 \\
\hline 2003 & $90,176.50$ & $12,10,033.10$ & 7.5 \\
\hline 2004 & $54,981.20$ & $15,19,242.70$ & 3.6 \\
\hline 2005 & $50,672.60$ & $18,98,346.40$ & 2.7 \\
\hline 2006 & $25,713.70$ & $26,09,289.40$ & 0.99 \\
\hline 2007 & $41,100.40$ & $48,20,695.70$ & 0.85 \\
\hline 2008 & $13,512.20$ & $77,99,400.10$ & 0.17 \\
\hline 2009 & $16,366.50$ & $96,67,876.70$ & 0.17 \\
\hline 2010 & $12,550.30$ & $91,98,173.10$ & 0.14 \\
\hline 2011 & $15,611.70$ & $96,14,445.80$ & 0.16 \\
\hline 2012 & $13,863.50$ & $1,04,40,956.30$ & 0.13 \\
\hline 2013 & $15,353.00$ & $1,15,43,649.90$ & 0.13 \\
\hline 2014 & $69,697.20$ & $5,00,46,686.10$ & 0.14 \\
\hline
\end{tabular}




\section{Literature Review}

It has been estimated that SMEs accounted for about 70 percent of total industrial employment in the country Olusoji [12]; therefore, whatever the definition of SMEs, and/or the size of the economy, the growth of SMEs is very crucial to the growth of that economy. Audretsch [13] concluded from his study on the analysis of SMEs role in United States, that they contribute the greatest amount of net employment to the economy. Weller (2004) argues that development of SMEs can reduce poverty and regional disparities as SMEs provide job access to less qualified and/or young people. Luetkenhorst [14] also argues that SMEs are important in applying new technologies to better satisfy consumer needs and contribute most innovations in relatively immature and un-concentrated economies. He posits further that SMEs help to build up an industrial system that is interlinked with significant positive externalities to surrounding economy, which is critical in attracting foreign direct investment.

Oluba [15] summarizes the contribution of SMEs to an economy, especially developing ones as: greater utilization of raw materials, employment generation, encouragement of rural development, development of entrepreneurship, mobilization of local savings, linkages with bigger industries, provision of regional balance by spreading investments more evenly, provision of avenue for self-employment and provision of opportunity for training managers and semi-skilled workers. Ogunsiji et al. [16] argue that entrepreneurial orientation is the panacea to the ebbing productivity. They opine that in Nigeria, there is need for a non-stop growth, harmonious and balanced blend of resources with the other engines of growth. Each of these engines of growth like people, market, capital, technology and organization can only flower and blossom fully where the efficacy of entrepreneurial orientation is appreciated and implemented

Chidi et al. [17] investigated the challenges confronting human capital development in Small and Medium-sized Enterprises (SMEs) in Nigeria. They find that human capital development in Nigerian SMEs leaves much to be desired. They recommend the need to address the issues of human capital development in SMEs and for SMEs to embrace the investment in people criteria if the desired corporate and national goals are to be realized. Afolabi [18] examined the growth effect of Small and Medium Enterprises (SMEs) financing in Nigeria. The study reveals that SMEs output proxied by wholesale and retail trade output as a component of gross domestic product and commercial banks' credit to SMEs have significant effect on economic growth. This implies that SMEs financing is an impetus and a driving force for economic growth in Nigeria.

Bamidele [19] studied that financing of Small and Medium scale Enterprises (SMEs) in Amuwo Odofin Local Government of Lagos State, Nigeria. The study examined how government and other agencies finance SMEs in Amuwo Odofin Local Government area of Lagos State. The study was hinged to network theory. The major concern of the theory is the objective pattern of ties linking the agencies, individuals and groups of the society. The agencies in this study include banks, cooperative societies, and government, among others. Quantitative and qualitative methods were used to collect data for the study. Fifty (50) samples of respondents were selected from the Local Government Area. The data gathered was analyzed using descriptive statistics such as frequency distribution, while the qualitative data was subjected to content and descriptive analysis. The study shows that government and other financial institutions have not done enough in supporting SMEs. In what needs to be done by government and other financial institutions saddled with the responsibility of funding SMEs, in order for SMEs to play their role of improving the economy, more loan should be given with an appropriate extension of deadlines for payment, create good job for people in order for them to save some amount of money and become self-employed, encourage and support existing SMEs, by making policies that would be beneficial to SMEs, create enabling investment environment, such as infrastructural development.

Onokoya, Fasanya and Abdulrahman 2013 examined the impact of financing small scale enterprises on economic growth in Nigeria using a quarterly time series data from 1992 to 2009. The study combined several econometric estimation techniques. The findings shows that loan to small scale entrepreneurs have a positive impact on the economic performance while interest rate has a negative impact on economic growth. The study thereby concludes that the greatest or worst problem confronting SMEs in Nigeria is managerial capacity. Access to capital or finance is necessary but not a sufficient condition for successful entrepreneurial development. Eigbiremolen et al. [20] examined small and medium scale enterprises and economic growth in Nigeria using an econometric analysis. The co-integrating regression result indicates that SMEs are statistically significant in the determination of economic growth. This means that SMEs remain indispensable in our pursuit of economic growth and development as a nation. In addition, SMEs positively impact economic growth. That implies a boost to the economy for every increase in the operations and activities of SMEs. The added control variables, Real Interest Rate (RINTR), Inflation (INF) and Money Supply (MS) are all statistically significant in explaining economic growth, with MS impacting economic growth positively, while RINTR and INF exhibit negative effects. The granger causality test reveals a unidirectional causality between SMEs and economic growth, running from the former to the latter.

Lemuel [21] investigated the financing options for small and medium enterprises: exploring the non - bank financial institution as an alternative means of financing in Nigeria and find that the majority of the employed populations are engaged in SMEs in Nigeria. He therefore concludes that if meaningful development 
is to be attained in the economy of the country, there has to be sustainable funding for the SMEs. Modinat et al. [6] examined capital market and the development of small and medium scale enterprises in Nigeria. The paper finds that the growth in the transactions of the quoted companies in the capital market has been fluctuating over the years and concludes that the incorporation of the SMEs into the stock exchange will enhance the growth in the transactions of the capital market in Nigeria.

\section{Problems and challenges associated with financing small scale enterprises}

According to Nwankwo [8], the centrality of the SMEs in the economic development of any nation is unquestionable as it is doubtful if any part of an economy can go without SMEs, their products and their services. They, in fact, are the nurseries and universities for big businesses. The represent the foundation head of vitality for the national economy. Flexibility as well as low startup and operating cost has enabled SMEs to spring up, reposition and adjust themselves quickly in response to market and economic changes. Moreover, they easily expand or contract in a short time. SMEs have not only survived the impact of big enterprises and the law of economies of small scale but have carved niches for themselves which enable them to co-exist with big enterprises Nwankwo [8]. In general, the most common problems for SMEs in Nigeria like most countries of the world are the lack of access to market information and technologies, low quality of human resources and the lack of access to capital. Despite the efforts by financial institutions and public-sector bodies to close the funding gaps SMEs continue to experience difficulty in obtaining risk capital.

These funding gaps relate to firm size, risk, knowledge and flexibility. SMEs borrowing requirements are small and frequently do not appeal to financial institutions. More collateral may be required than SMEs can pledge. Financial institutions may lack the expertise in understanding small and medium knowledge base business. Also flexibility in terms and conditions of financing that SMEs require may not be available Nwankwo [8]. He posits that infrastructural development such as poor electricity generation, high cost of doing business and registrations are some of the banes to SMEs operating in Nigeria.

All these were also captured in Oteh 2010 where she summed up some of the major challenges SMEs face as inadequate infrastructural facilities, shortage of skilled manpower, high rate of enterprises mortality, low level of entrepreneurial skills, lack of conducive operating environment, restricted market access and cumbersome regulatory requirements. One of the major difficulties SMEs come across, however, is the issue of access to finance. SMEs especially in developing countries suffer from lack of access to appropriate (term and cost) fund from both money and capital market. This is due in part to the perception of higher risk resulting in high mortality rate of the business, information asymmetry, poorly prepared project proposals, inadequate collateral, absence of a verifiable history of past credit obtained, lack of adequate historical records of the company transactions. Available evidence from previous research works show that SMEs do not keep proper account of transactions.

Despite all these challenges associated with SMEs financing, Banji [22], posits that studies by the International Finance Corporation (IFC) show that approximately $96 \%$ of Nigerian businesses are SMEs compared to 53\% in Europe. He stated that SMEs represent about $90 \%$ of the manufacturing/industrial sector in terms of number of enterprises and they contribute approximately $1 \%$ of Gross Domestic Product (GDP) as opposed to $40 \%$ in Asian countries and 50\% in the USA and Europe. Finally, the vast majority of empirical studies that analyze the determinants of the firm financing usually examine large publicly listed companies with a widely spread ownership. These companies often raise finance by using corporate debts on the capital markets Zingales [23].

\section{Methodology}

The study adopted a descriptive survey. 80 small and medium enterprises in Anambra state were sampled, 40 each from Onitsha and Nnewi. The choice of the two cities was guided by the fact that they have large clusters of small and medium enterprises in the state. Questionnaires were administered on the owners of these SMEs and/ or representatives (in cases were the owner was not available as at the time of issuing the questionnaire). All the questionnaires were returned and were checked for plausibility, honesty and completeness resulting in all cases being usable. The hypothesis developed was tested using the Chi-Square $\left(\mathrm{X}^{2}\right)$. Simple tabulation was used to present the survey findings, percentage distributions of the respondents were equally used [24,25].

\section{Data analysis and presentation}

Table 2: Shows that the respondents were drawn as follows: Pharmaceuticals 12 (15\%), Automobile/servicing parts 14 (17.5\%), Chemical/soap/plastic/paints 15 (18.75), Confectioneries/ biscuits $7(8.5)$, Transport 5 (6.25), Oil and gas 9 (11.25).

\begin{tabular}{|c|c|c|}
\hline Types of Industry & Frequency & Percentages \\
\hline Pharmaceuticals & 12 & 15 \\
\hline Automobile/servicing parts & 14 & 17.5 \\
\hline Chemical/soap/plastic/paints & 15 & 18.75 \\
\hline Confectioneries/Biscuit & 7 & 8.75 \\
\hline Transport & 5 & 6.25 \\
\hline Oil and Gas & 9 & 11.25 \\
\hline Food processing/Beverages & 18 & 22.5 \\
\hline Total & 80 & 100 \\
\hline
\end{tabular}

Table 2 shows that the respondents were drawn as follows: Pharmaceuticals 12 (15 per cent), Automobile/servicing parts 14 (17.5 per cent), Chemical/soap/plastic/paints 15 (18.75), Confectioneries/ biscuits 7 (8.5), Transport 5 (6.25), Oil and gas 9 (11.25). 
Table 3 above shows that $32.5 \%$ of the SMEs have no knowledge of the operations and activities of the capital market. Other reasons for not procuring fund from the capital market includes; fear of losing control of their companies to shareholders (22.5\%), $17.5 \%$ of SMEs cannot procure long term fund because of unfavourable listing requirements, while $11.25 \%$ are away from the epicentre of capital market activities. Furthermore, $11.25 \%$ of the SMEs can easily source fund and soft loan from government owned financial institutions, 2.5 indicated that high credit risk may result from sudden changes in economic and competitive environment, $2.5 \%$ indicated fear of liquidity that may result from under subscription of its shares.

Table 3: Distribution of SMEs on why they do not procure long term finance from the capital market.

\begin{tabular}{|c|c|c|}
\hline Reasons & Number of SMEs & Percentages \\
\hline Lack of information about the activities of the capital market & 26 & 32.5 \\
\hline Listing requirements are not favourable & 14 & 17.5 \\
\hline $\begin{array}{l}\text { Fear of liquidity that may result from low demand of securities/under subscription to its } \\
\text { shares }\end{array}$ & 2 & 2.5 \\
\hline $\begin{array}{l}\text { High credit risk that may result from sudden changes in economic and competitive environ- } \\
\text { ment }\end{array}$ & 2 & 2.5 \\
\hline Fear of losing the control of their companies to shareholders & 18 & 22.5 \\
\hline Distance of SMEs from the place of action & 9 & 11.25 \\
\hline The availability of fund and soft loan from government owned financial institutions & 9 & 11.25 \\
\hline Total & 80 & 100 \\
\hline
\end{tabular}

Source: Field survey 2014.

A careful look at Table 4 above reveals that the cost of procuring fund from the capital market is expensive and unaffordable by most SMEs which is $28.75 \%$, and the issue of reduction of listing requirements for SMEs at $22.5 \%, 18.5 \%$ accepted that the amount to be raised should be limitless. This is in accordance with what the Nigerian Stock Exchange has done by making the amount to be raised limitless through the launch of the alternative securities market in 2013, while 20\% showed that shareholders should be allowed in taking management decision of their companies, $2.5 \%$ requested to submit only annual audited financial statement and $7.5 \%$ will procure fund if the minimum shareholders are reduced from 51 to 31 .

Table 5 indicates that about 72.50 per cent of the respondents supported the payment of an application fee of N100,000.00 while about 27.50 per cent considered it unaffordable. Also, about 80 per cent of the respondents agreed that number of shares to be listed should not be less than 15 per cent but not more than 85 per cent of total authorized shares while about 20 per cent agree otherwise. The table also indicates that about 62.5 per cent of them see the payment of an annual listing fee of N2, 000,000.00 as exorbitant.

\section{Test of hypothesis}

$\mathrm{Ho}^{1}$ : The Nigerian Stock Exchange listing requirements does not have any significant

influence on listing of SMEs on the exchange Analysis of Nigerian Stock Exchange (NSE) listing requirement affects SMEs listing on the exchange Observed Frequencies (fo) (Table 6). 
Table 4: Distribution of SMEs on the conditions they will be willing to procure long term fund from the capital market.

\begin{tabular}{|c|c|c|}
\hline Reasons & Number of SMEs & Percentages \\
\hline Reducing the cost of procuring long term fund from the capital market & 23 & 28.75 \\
\hline Relaxation of the listing requirements for SMEs & 18 & 22.5 \\
\hline Removing the limit on the amount that should be raised from the market & 15 & 18.75 \\
\hline Allow the owners of the SMEs to retain control & 16 & 20 \\
\hline Submitting only annual audited financial statement & 2 & 2.5 \\
\hline Reduction of minimum shareholders from 51 to 3 & 6 & 7.5 \\
\hline Total & 80 & 100 \\
\hline
\end{tabular}

Table 5: The degree to which Nigerian Stock Exchange (NSE) listing requirement affects SMEs.

\begin{tabular}{|c|c|c|}
\hline & Frequency & Percentages \\
\hline Very High Degree & 16 & 20 \\
\hline High Degree & 56 & 70 \\
\hline Low Degree & 8 & 10 \\
\hline Total & 80 & 100 \\
\hline
\end{tabular}

Source: Field Survey 2014

Table 6: The degree of agreement on the influence of NSE listing requirements on the SMEs, Ho1: The Nigerian stock exchange listing requirements does not have any significant influence on listing of SMEs on the exchange.

\begin{tabular}{|c|c|c|c|}
\hline Variables & Responses & Number of Responses & Percentages \\
\hline \multirow{4}{*}{$\begin{array}{l}\text { The initial application fee of N100, } 000.00 \text { for listing of SMEs } \\
\text { in the Nigeria Stock Exchange is affordable }\end{array}$} & Strongly agree, & 13 & 16.25 \\
\hline & Agree, & 45 & 56.25 \\
\hline & Disagree, & 17 & 21.25 \\
\hline & Strongly Disagree, & 5 & 6.25 \\
\hline \multirow[t]{2}{*}{ Total } & & 80 & 100 \\
\hline & Strongly agree, & 9 & 11.25 \\
\hline \multirow{3}{*}{$\begin{array}{c}\text { Shares to be listed should not be less than } 15 \% \text { of the total } \\
\text { share of the company while pre- listing investors holds a } \\
\text { maximum of } 85 \% \text { stake }\end{array}$} & Agree, & 55 & 68.75 \\
\hline & Disagree, & 10 & 12.5 \\
\hline & Strongly Disagree & 6 & 7.5 \\
\hline \multirow[t]{2}{*}{ Total } & & 80 & 100 \\
\hline & Strongly agree, & 2 & 2.5 \\
\hline \multirow{3}{*}{$\begin{array}{l}\text { The Nigerian Stock Exchange annual listing fee of N2,000, } \\
000.00 \text { for SMEs listed on the exchange is not on a high side } \\
\text { for most SMEs to conveniently afford as at when due }\end{array}$} & Agree, & 28 & 35 \\
\hline & Disagree, & 40 & 50 \\
\hline & Strongly Disagree & 10 & 12.5 \\
\hline Total & & 80 & 100 \\
\hline
\end{tabular}

Analysis of Nigerian Stock Exchange (NSE) listing requirement affects SMEs listing on the exchange observed frequencies (fo) (Table 7).

Table 7: Analysis of Nigerian Stock Exchange (NSE) listing requirement affects SMEs listing on the exchange Observed Frequencies (fo).

\begin{tabular}{|c|c|c|c|c|c|}
\hline Variables & SA & A & D & SD & Total \\
\hline A & 13 & 45 & 17 & 5 & 80 \\
\hline B & 9 & 55 & 10 & 6 & 80 \\
\hline C & 2 & 28 & 48 & 10 & 80 \\
\hline Total & 24 & 128 & 75 & 21 & 240 \\
\hline
\end{tabular}


Analysis of Nigerian Stock Exchange (NSE) listing requirement affects SMEs listing on the exchange expected frequencies (fe) (Table 8).

Table 8: Analysis of Nigerian Stock Exchange (NSE) listing requirement affects SMEs listing on the exchange Expected Frequencies (fe).

\begin{tabular}{|c|c|c|c|c|c|}
\hline Variables & SA & A & D & SD & Total \\
\hline A & 8 & 42.67 & 25 & 7 & 80 \\
\hline B & 8 & 42.67 & 25 & 7 & 80 \\
\hline C & 8 & 42.67 & 25 & 7 & 80 \\
\hline Total & 24 & 128 & 75 & 21 & 240 \\
\hline
\end{tabular}

Source: Field Survey 2014

Table 9: Analysis of the observed and expected frequencies for empirical test using chi-square (X2).

\begin{tabular}{|c|c|c|c|c|c|}
\hline Variables & $\mathbf{0}$ & $\mathbf{E}$ & $\mathbf{0 - e}$ & $\mathbf{( o - e )}^{2}$ & (o-e) $^{2} / \mathbf{e}$ \\
& 58 & 56.67 & 1.33 & 1.7689 & 0.03121 \\
$\mathrm{~A}$ & 22 & 32 & -10 & 100 & 3.125 \\
& 64 & 56.67 & 7.33 & 53.7289 & 0.9481 \\
B & 16 & 32 & -16 & 256 & 8 \\
& 30 & 56.67 & -26.67 & 711.289 & 12.551 \\
C & 58 & 32 & 26 & 676 & 21.125 \\
Total & & & & & 45.78 \\
\hline
\end{tabular}

Degree of freedom $(\mathrm{DF})=6$

Empirical Test $(\mathrm{X} 2)=45.78$

Critical Value at $5 \%$ level significance $=12.592$

Analysis of the observed and expected frequencies for empirical test using chi-square $\left(\mathbf{X}^{2}\right)$ : Decision rule: Reject the null hypothesis (Ho), when $\mathrm{X}^{2}>12.592$ (Table 8) Empirical test, $\mathrm{X}^{2}$ (45.78) is greater than the corresponding critical value of 12.592 , that is $45.78>12.592$ the null hypothesis which states that Nigerian Stock Exchange listing requirements does not have any significant influence on listing of SMEs on the exchange is rejected while the alternative hypothesis which states that Nigerian Stock Exchange listing requirements has significant influence on listing of SMEs on the exchange is accepted (Table 9).

\section{Conclusion and Recommendation}

This research work examined why SMEs do not procure long term finance from the capital market as well as determining the conditions on which SMEs will be willing to procure long term fund from the capital market. Findings from the survey show that information about the activities and operations of the capital market among SMEs specifically, in respect of its relevance to access to long term funding for the SMEs is still low. The few SMEs that are aware of such vital information fear losing control of their companies to wealthy shareholders. This is based on the mind-set that some people cannot start a business but will want to control the companies founded by others because of large number of shares they can buy from such companies if listed on the exchange. Furthermore, the study found cost of listing and requirements as obstacles to procuring fund from the capital market. The findings exhibit clearly that the major bottleneck to SMEs accessing fund from the capital market is the listing challenge. In the light of this, the Nigerian Stock Exchange should carefully consider the constraints identified by the SMEs with a view to reviewing them for the benefit of SMEs without jeopardizing the integrity of the Nigerian Stock Exchange. Apart from relaxing the listing requirements, other avenues of reducing the cost burden of SMEs is to formulate policies that would attract SMEs particularly in the aspect of excise duties, interest rate, tax holidays and so on, to make long term funding from the capital market attractive.

\section{References}

1. Hallberg K (2000) A market-oriented strategy for small and medium scale enterprises. International Finance Corporation, The World Bank, Washington, USA, pp. 40

2. Olutunla, GT, Obamuyi, TM (2008) An empirical analysis of factors associated with the profitability of small and medium enterprises in Nigeria. African Journal of Business Management 2(10): 195-200.

3. William ES (2006) Supporting the growth of small and medium enterprises. Address to the Nova Committee of the Trinidad and Tobago Chamber of Industry and Commerce, Port of Spain, Spain. 
4. Abereijo, Fayomi (2005) Innovative approach to SME financing in Nigeria: A review of Small and Medium industries Equity Investment Scheme (SMIEIS). J Soc Sci 11(3): 219-227.

5. Levitsky J (1996) Support system for SMEs in developing countries: A review paper commissioned by the small and medium industries branch, United Nations Industrial Development Organization, Vienna, Austria.

6. Modinat 00, Edwin EE (2012) Capital market and the development of small and medium scale enterprises in Nigeria. Journal of Business and Management 5(4): 5-12.

7. Anyanwu JC, Onyefusi O0, Oaikhenam A, Dinow FA (1997) The Nigeria capital market in the structure of Nigeria economy 1960-1997. Joanese Educational Publishers Ltd, Onitsha, Nigeria.

8. Nwakoby CIN (2012) A financial characteristic of bank financing of SMEs: The Anambra state experience, Nigeria.

9. Udechukwu FN (2003) Survey of small and medium scale industries and their potentials in Nigeria Being a paper presented at the Centra Bank of Nigeria (CBN) seminar on small and medium industries equity investments, Lagos, Nigeria.

10. Akingunola RO (2011) Small and medium enterprises and economic growth in Nigeria: An assessment of financing options. Pakistan Journal of Business and Economic Review 2(1): 77-97.

11. Osa Afiana L (2004) Contemporary approaches to financing micro, Small and Medium Enterprises (MSMA) in Nigeria. 15 ${ }^{\text {th }}$ international conference of World Association for Small and Medium Enterprises (WASME), Abuja, Nigeria.

12. Olusiji MO (1999) Small and medium scale enterprises of the Nigeria experiences Nigeria. Journal of Economic History 1(2).

13. Audretsch DB (2001) The economic role of Small and Medium Enterprises: The United States world bank workshop on SMEs.

14. Luetkenhorst W (2004) Economic development, the role of Small and Medium Scale Enterprises (SMEs) and the rationale for donor support: Some reflection in recent trends and best practices a paper presented at SMEs group meeting, Hanoi, Vietnam.
15. Oluba $O$ (2009) The impact of microfinance on the entrepreneurial development: the case of Nigeria. International Conference on Administration and Business, ICEA-FAA Bucharest, Nigeria, pp. 536-545.

16. Ogunsibi SA, Ladamu WK (2010) Entrepreneurial orientation as a panacea for the ebbing productivity in Nigeria Small and Medium Scale Enterprises: A theoretical perspective international business. Research Journal 3(4): 45-58.

17. Chidi C, Shadere O (2011) Managing human capital development in small and medium enterprises environmental research. Engineering and Management Journal 2(52): 14-24.

18. Afolabi, Oluseye (2013) Growth effect of Small and Medium Enterprises (SMEs) financing in Nigeria. Journal of African Macroeconomic Review 3(1): 192-205.

19. Bamidele R (2013) Small and Medium Scale Enterprises (SMEs): A panacea for economic growth in Nigeria. Journal of Management and Corporate Finance.

20. Eigbiremolen GO, Igberaese FI (2013) Small and medium enterprises financing and economic growth in Nigeria: An econometric analysis. Journal of Economic and Sustainable Development 4(19): 52-56.

21. Lemuel E (2009) Financing options for Small and Medium Scale Enterprises (SMEs): Exploring the non-bank financial institution as an alternative means of financing. Master's Degree Thesis in Business Administration, Sweden.

22. Banji 00 (2007) SME: Issues, challenges and prospect a conference paper. Financial System Strategy, Nigeria.

23. Zinagales L (2001) In Search of new foundation. The Journal of Finance 44(4): 1632-1653.

24. Oreoluwa AR (2011) Small and medium scale enterprises and economic growth in Nigeria: An assessment of financing options. Pakistan Journal of Business and Economic Review 2(1)

25. Obamuyi TM (2007) An exploratory study of loan delinquency among Small and Medium Scale Enterprises (SMEs) in Ondo state of Nigeria. Labor and management in development 8: 1-11.
Creative Commons Attribution 4.0

International License

For possible submissions Click Here

\section{Submit Article}

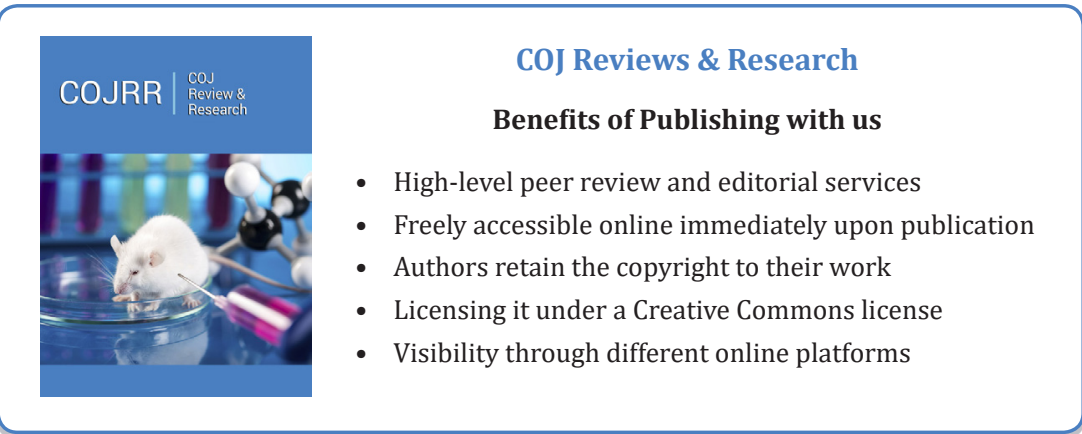

